\title{
An Approach to Sustainable Homes by Applying Control Science
}

\author{
Kazutoshi Fujihira \\ 2-3-1-306 Nagayama, Tama, Tokyo, 206-0025 Japan \\ kkg@mve.biglobe.ne.jp
}

Keywords: Control system, design, material element, spatial element, sustainability checkup.

\begin{abstract}
This study shows a two-step method for smooth design of control systems for sustainable homes. First, we select important elements of the standard home on the basis of two factors, material and space, and determine the relationship between these elements and sustainable development. Next, we demonstrate the second step, a sustainability checkup on a home as an object. The results of the sustainability checkup can smoothly identify necessary system components and help to design control laws, which confirms the effectiveness of this method.
\end{abstract}

\section{Introduction}

Nowadays, humankind is facing a variety of environmental and social problems such as global warming, the destruction of ecosystems, the tight supply-demand situation for oil and metals, poverty, and conflicts. It is our ultimate goal as humans to solve or prevent such problems and achieve sustainable development or sustainability. Achieving sustainable development is a goal-oriented task; therefore, applying the science of control is a rational approach. Quickly realizing this point, I started conducting research. The finished research has shown the basic control system for sustainable development and an educational methodology for sustainable development with case studies [1,2].

Now I again show the basic control system for sustainable development (Fig. 1) [1, 2]. Controlled objects are human activities which cause environmental or social problems; the units of human activities can be various. Controlled variables are the variables that relate to human activities and need to be controlled for solving or preventing the problems. 'Disturbances' are harmful influences on controlled objects caused by environmental and social problems. The purpose of control is identified as sustainable development. As shown in Fig. 2, sustainable development requires both 'Fundamental Stability' and 'Internal Stability,' in order to accomplish the long-term well-being of all humankind, or ultimate end, within the finite global environment and natural resources, or absolute limitations [1,2]. 'Fundamental Stability' means environmental stability and a stable supply of natural resources; the conditions for Fundamental Stability are environmental preservation and the sustainable use of natural resources. On the other hand, 'Internal Stability'

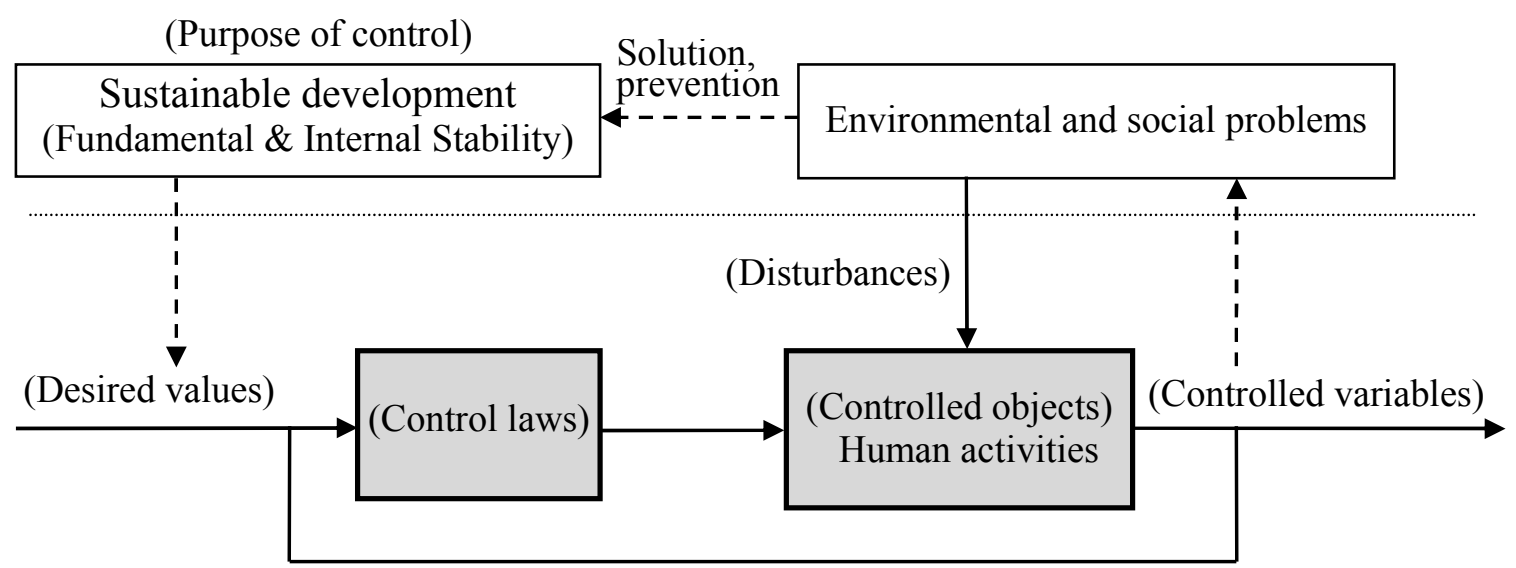

Fig. 1 The basic control system for sustainable development 


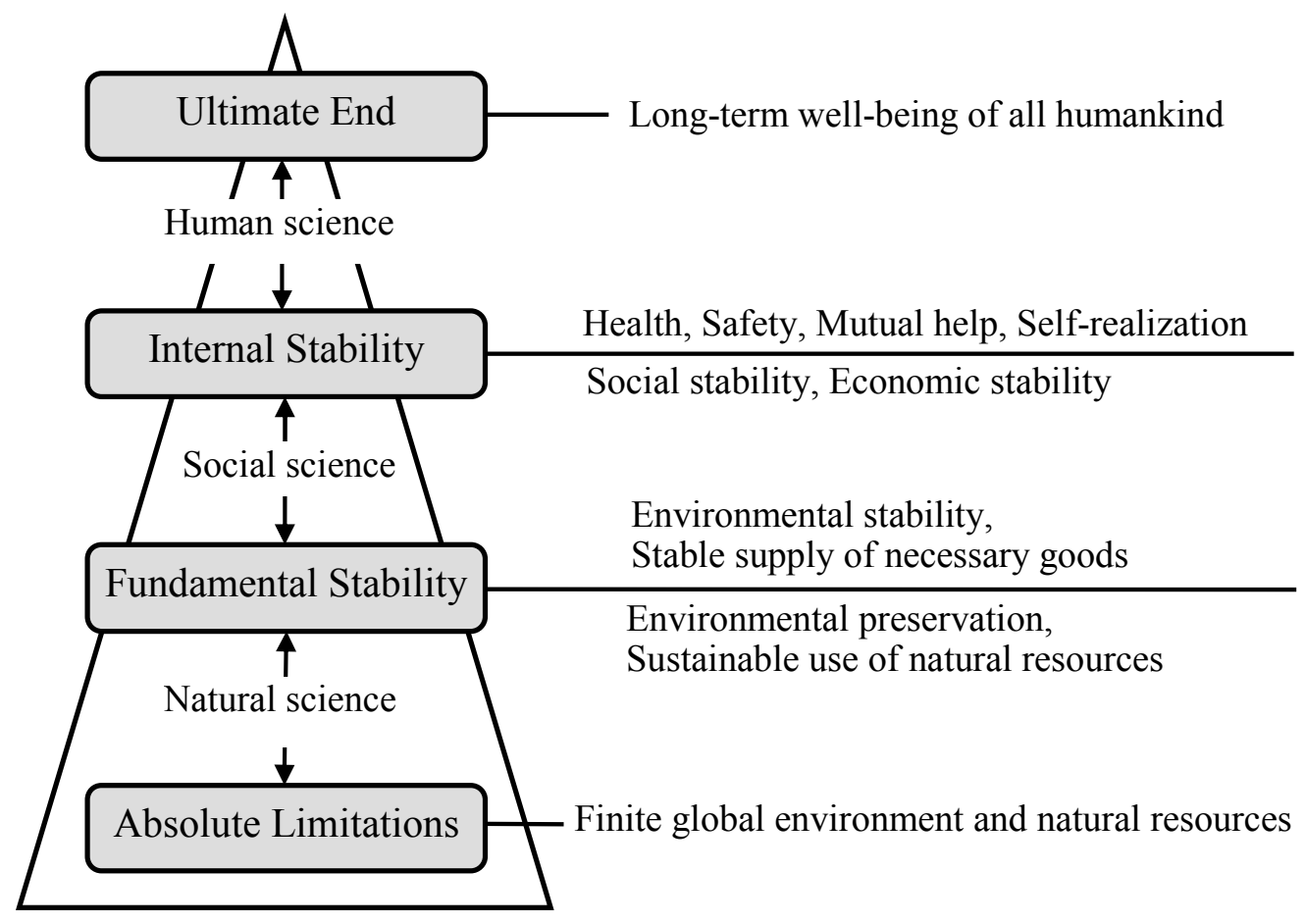

Fig. 2 The model of sustainable development

means social and economic stability; the conditions for Internal Stability are health, safety, mutual help and self-realization, which are essential for well-being of humans. The three sciences, which are placed between 'Absolute Limitations,' 'Fundamental Stability,' 'Internal Stability' and 'Ultimate End,' are necessary to investigate each relationship.

Desired values are derived from the purpose of control, or sustainable development. The control objective is to adjust the controlled variables to the desired values. Furthermore, the control system requires designing and implementing 'control laws.'

Here this study discusses a two-step method for designing practical control systems for sustainable homes, choosing the home as a unit of human activities. The next chapter provides the first step of this method, determining the relationship between the standard home and sustainable development. After that, we demonstrate the second step, a sustainability checkup on a home as an object. The results of the sustainability checkup clearly show the effectiveness of this method.

\section{Determining the relationship between the standard home and sustainable development}

In the first step, system designers need to select important elements of the standard home and determine the relationship between such elements and sustainable development [3].

Two factors on selecting elements of the standard home. In order to select important elements of the standard home, we have analyzed two main factors: material and space (Table 1). The first factor material regards the home as an object which contains material elements such as framework, exterior, interior finishing, and piping. Moreover, when observing the details of such material

Table 1 Factors on selecting elements of the home

\begin{tabular}{|c|c|c|}
\hline Factor & Material & Space \\
\hline $\begin{array}{c}\text { Examples } \\
\text { of elements } \\
\text { (details) }\end{array}$ & $\begin{array}{l}\text { (a) Framework (pillar, beam, etc.) } \\
\text { (b) Exterior (roof, outer wall, etc.) } \\
\text { (c) Interior finishing (floor, wall, ceiling, etc.) } \\
\text { (d) Piping (water pipe, gas pipe, etc.) }\end{array}$ & $\begin{array}{l}\text { (a) Room (living room, bedroom, dining } \\
\text { room, kitchen, bathroom, etc.) } \\
\text { (b) Area (garden area, exterior area, etc.) }\end{array}$ \\
\hline
\end{tabular}


elements, they can be broken down further into smaller material elements; for example, framework includes pillars and beams. On the other hand, the other factor space regards the home as an object which consists of spatial elements such as rooms and areas. If regarding the home as a mass of rooms, we can find more specific spatial elements; for instance, a living room and bedroom.

This study has observed the standard home based on both of these factors. As a result, we have selected important elements, as shown in the central column of Table 2. "Material elements" are from 'framework' to 'fence;' "spatial elements" are from 'rooms used at daytime' to 'garden area.'

Relationship between the Standard Home and Sustainable Development. After selecting the elements of the standard home, we have determined the relationship between these elements and sustainable development. Table 2 demonstrates the essentials of such relationship. The left side of Table 2 shows the relationship between the elements and Fundamental Stability; the right side demonstrates the relationship between the elements and Internal Stability. Considering the relationship between each element and the stability conditions, we have identified variables which indicate the degree of stability. In addition, we have set the desired values of these variables that can achieve stability.

Table 2 Relationship between the standard home and sustainable development [Essentials]

\begin{tabular}{|c|c|c|c|c|c|c|}
\hline \multicolumn{3}{|c|}{$\begin{array}{c}\text { Relationship between the element and } \\
\text { Fundamental Stability }\end{array}$} & \multirow{2}{*}{ Element } & \multicolumn{3}{|c|}{$\begin{array}{l}\text { Relationship between the element and } \\
\text { Internal Stability }\end{array}$} \\
\hline $\begin{array}{l}\text { Stability } \\
\text { condition }\end{array}$ & Desired value & Variable & & Variable & Desired value & $\begin{array}{l}\text { Stability } \\
\text { condition }\end{array}$ \\
\hline $\begin{array}{l}\text { Sustainable use } \\
\text { of resources }\end{array}$ & $\begin{array}{l}\text { JHPIS Sec. } 3-1: \\
\text { Grade } 2 \text { or over }\end{array}$ & Durability & \multirow[b]{2}{*}{ Framework } & $\begin{array}{l}\text { Resistance to } \\
\text { earthquakes }\end{array}$ & $\begin{array}{l}\text { JHPIS Sec. } 1-1: \\
\text { Grade } 2 \text { or over }\end{array}$ & Safety \\
\hline $\begin{array}{l}\text { Sustainable use } \\
\text { of resources }\end{array}$ & $\begin{array}{c}\text { CASBEE } \mathrm{LR}_{\mathrm{H}} 2 \\
\text { 1.1: Level } 4 \\
\text { or over }\end{array}$ & Raw materials & & $\begin{array}{l}\text { Wind } \\
\text { resistance }\end{array}$ & $\begin{array}{l}\text { JHPIS Sec. } 1-4 \text { : } \\
\text { Grade } 1 \text { or over }\end{array}$ & Safety \\
\hline $\begin{array}{l}\text { Sustainable use } \\
\text { of resources }\end{array}$ & $\begin{array}{l}\text { JHPIS Sec. } 3-1: \\
\text { Grade } 2 \text { or over }\end{array}$ & Durability & Exterior & Fire resistance & $\begin{array}{l}\text { JHPIS Sec. } 2-6: \\
\text { Grade } 3 \text { or over }\end{array}$ & Safety \\
\hline $\begin{array}{l}\text { Enviro-preserve } \\
\text { Sustainable use } \\
\text { of resources }\end{array}$ & $\begin{array}{l}\text { JHPIS Sec. 5-1: } \\
\quad \text { Grade } 4\end{array}$ & $\begin{array}{c}\text { Thermal } \\
\text { insulation } \\
\text { performance }\end{array}$ & $\begin{array}{l}\text { Thermal } \\
\text { insulation }\end{array}$ & $\begin{array}{c}\text { Thermal } \\
\text { insulation } \\
\text { performance }\end{array}$ & $\begin{array}{l}\text { JHPIS Sec. 5-1: } \\
\quad \text { Grade } 4\end{array}$ & Health \\
\hline $\begin{array}{l}\text { Enviro-preserve } \\
\text { Sustainable use } \\
\text { of resources }\end{array}$ & $\begin{array}{l}\text { JHPIS Sec. 5-1: } \\
\text { Grade } 4\end{array}$ & $\begin{array}{c}\text { Thermal } \\
\text { insulation } \\
\text { performance }\end{array}$ & \multirow{2}{*}{$\begin{array}{l}\text { Windows } \\
\& \text { doors }\end{array}$} & $\begin{array}{l}\text { Area of } \\
\text { window } \\
\text { openings }\end{array}$ & $\begin{array}{c}20 \% \text { of the floor } \\
\text { area or more }\end{array}$ & Health \\
\hline $\begin{array}{l}\text { Enviro-preserve } \\
\text { Sustainable use } \\
\text { of resources }\end{array}$ & $\begin{array}{l}\text { CASBEE } \mathrm{Q}_{\mathrm{H}} 1 \\
\text { 1.1.2: Level } 4 \\
\text { or over }\end{array}$ & $\begin{array}{c}\text { Sunlight } \\
\text { adjustment } \\
\text { capability }\end{array}$ & & $\begin{array}{c}\text { Sound } \\
\text { insulation } \\
\text { performance }\end{array}$ & $\begin{array}{l}\text { JHPIS Sec. } 8-4: \\
\text { Grade } 2 \text { or over }\end{array}$ & Health \\
\hline $\begin{array}{l}\text { Sustainable use } \\
\text { of resources }\end{array}$ & $\begin{array}{c}\text { CASBEE LR }_{H} 2 \\
\text { 1.4: Level } 4 \\
\text { or over } \\
\end{array}$ & Raw materials & $\begin{array}{l}\text { Interior } \\
\text { finishing }\end{array}$ & $\begin{array}{c}\text { Formaldehyde } \\
\text { emission }\end{array}$ & $\begin{array}{l}\text { JHPIS Sec. 6-1: } \\
\text { Grade } 3\end{array}$ & Health \\
\hline $\begin{array}{l}\text { Sustainable use } \\
\text { of resources }\end{array}$ & $\begin{array}{l}\text { JHPIS Sec. } 4-1: \\
\text { Grade } 3 \text { or over }\end{array}$ & $\begin{array}{c}\text { Consideration } \\
\text { for maintenance }\end{array}$ & Piping & & & \\
\hline $\begin{array}{l}\text { Enviro-preserve } \\
\text { Sustainable use } \\
\text { of resources }\end{array}$ & $\begin{array}{l}\text { Energy usage } \\
\text { of the whole } \\
\text { home or more }\end{array}$ & $\begin{array}{c}\text { Harnessed } \\
\text { natural energy }\end{array}$ & $\begin{array}{c}\text { Equipment } \\
\text { for harnessing } \\
\text { natual energy }\end{array}$ & & & \\
\hline \multirow{2}{*}{$\begin{array}{l}\text { Enviro-preserve } \\
\text { Sustainable use } \\
\text { of resources }\end{array}$} & \multirow{2}{*}{$\begin{array}{c}\text { Hedge or } \\
\text { Resources-saving } \\
\text { materials }\end{array}$} & \multirow{2}{*}{ Material } & \multirow{2}{*}{ Fence } & \multirow{2}{*}{ Form } & $\begin{array}{l}\text { Not blocking } \\
\text { sight line }\end{array}$ & Safety \\
\hline & & & & & $\begin{array}{l}\text { Not blocking } \\
\text { communication }\end{array}$ & Mutual help \\
\hline \multirow[t]{2}{*}{\begin{tabular}{|l} 
Enviro-preserve \\
Sustainable use \\
of resources
\end{tabular}} & $\begin{array}{l}\text { Places receiving } \\
\text { a lot of sunlight }\end{array}$ & $\begin{array}{l}\text { Places in the } \\
\text { home }\end{array}$ & $\begin{array}{l}\text { Rooms used } \\
\text { at daytime }\end{array}$ & & & \\
\hline & & & $\begin{array}{l}\text { Specified } \\
\text { bedroom }\end{array}$ & $\begin{array}{c}\text { Relation with } \\
\text { toilet and bath }\end{array}$ & On the same floor & $\begin{array}{l}\text { Health } \\
\text { Safety }\end{array}$ \\
\hline $\begin{array}{l}\text { Enviro-preserve } \\
\text { Sustainable use } \\
\text { of resources }\end{array}$ & $\begin{array}{l}\text { Building close } \\
\text { together }\end{array}$ & Arrangement & $\begin{array}{l}\text { Rooms water } \\
\text { is used }\end{array}$ & & & \\
\hline Enviro-preserve & $40 \%$ or more & $\begin{array}{l}\text { Ratio to the } \\
\text { exterior area }\end{array}$ & Garden area & & & \\
\hline
\end{tabular}

[Note] (1) JHPIS is an abbreviation for the Japan Housing Performance Indication Standards. (2) CASBEE means Comprehensive Assessment System for Building Environment Efficiency for Home (Detached house) - Technical Manual 2007 Edition. 
Choosing several elements from Table 2, I concretely describe the relationship. [Material elements]

- Framework: Considering the relationship between "framework" and "sustainable use of natural resources,' a condition for Fundamental Stability, we have identified 'durability' and 'raw materials' as variables. The desired values of 'durability' and 'raw materials' are the 'deterioration resistance grades' of the Japan Housing Performance Indication Standards (JHPIS) [4] and the 'assessment levels of resources saving' of CASBEE for Home, or Comprehensive Assessment System for Building Environmental Efficiency for Home [5], respectively. On the other hand, considering the relationship with 'safety,' a condition of Internal Stability, we have selected 'resistance to earthquakes' and 'wind resistance' as variables, and the 'seismic resistance grades' and the 'wind-resistant grades' of JHPIS [4] as their desired values.

- Thermal insulation: 'Performance' of "thermal insulation" is significant since it relates to both Fundamental Stability and Internal Stability. An increase in thermal insulation performance leads to environmental preservation and sustainable use of natural resources through a decrease in energy usage for air conditioning and heating. Meanwhile, it also promotes the health of occupants through the stabilization of the indoor temperature. The desired value of thermal insulation performance has been set at the highest grade in the "Energy-Saving Action Grades" of JHPIS [4].

[Spatial elements]

- Specified bedrooms: A "specified bedroom" means a bedroom which is used or expected to be used by elderly or wheelchair users. Such a room and the bathroom area should be arranged on the same floor. This arrangement enables such occupants to use the toilet and bath easily.

- Rooms where water is used: "Rooms where water is used" includes a kitchen, toilet, bath, and washing room. If these rooms are built close together, the total length of water piping and drainage piping can be reduced. Moreover, this consideration helps reduce heat loss from hot-water piping.

\section{Sustainability Checkup on a Home as an Object}

In the second step, system designers measure or estimate the variables of a home as an object and assess them by comparing with the desired values [3]. Table 3 shows an example of sustainability checkup on a home as an object. In this case, the checkup results are assessed in three grades: A, B and $C$. "A" means that the variable reaches the desired value. "B" signifies that the variable falls below the desired value. "C" means that the variable falls substantially below the desired value.

Here I view the checkup results, choosing several elements from Table 3. As for "framework," two of the four variables, 'durability' and 'resistance to earthquakes' are assessed at B because they are lower than the desired values. The 'performance' of the "thermal insulation" is assessed at $\mathrm{C}$ since it falls substantially below the desired value. The 'arrangement' of "rooms where water is used' is assessed at A because such rooms are built close together.

After the sustainability checkup, the variables that are assessed at B or C need to be identified as "controlled variables." The variables assessed at C are especially required to be identified as "controlled variables." In addition, this home is naturally identified as a "controlled object" because it includes controlled variables. Moreover, such a sustainability checkup table enables system designers to find at a glance the following: the elements which should be controlled, controlled variables and their desired values. Therefore, it enables them to understand both what should be controlled and the courses of control.

\section{Discussion}

This study has shown the two-step method for designing practical control systems for sustainable homes, based on the basic control system for sustainable development shown in Fig. 1. First, we have provided the first step of this method. That is to say, after selecting important elements of the standard home based on the two factors material and space, we have determined the relationship between such elements and sustainable development. Next, we have shown the second step of this 
Table 3 An example of sustainability checkup on a home as an object [Essentials]

\begin{tabular}{|c|c|c|c|c|c|c|c|c|}
\hline \multicolumn{4}{|c|}{$\begin{array}{l}\text { Relationship between the element and } \\
\text { Fundamental Stability }\end{array}$} & \multirow[b]{2}{*}{ Element } & \multicolumn{4}{|c|}{$\begin{array}{l}\text { Relationship between the element and } \\
\text { Internal Stability }\end{array}$} \\
\hline Desired value & $\begin{array}{c}\text { Ass- } \\
\text { ess. }\end{array}$ & $\begin{array}{c}\text { Measured or } \\
\text { estimated } \\
\text { value }\end{array}$ & Variable & & Variable & $\begin{array}{l}\text { Measured or } \\
\text { estimated } \\
\text { value }\end{array}$ & $\begin{array}{l}\text { Ass- } \\
\text { ess. }\end{array}$ & Desired value \\
\hline $\begin{array}{l}\text { JHPIS Sec. } \\
\text { 3-1: Grade } 2 \\
\text { or over }\end{array}$ & B & 40 years & Durability & \multirow[b]{2}{*}{$\begin{array}{l}\text { Frame- } \\
\text { work }\end{array}$} & \begin{tabular}{|c|} 
Resistance \\
to \\
earthquakes \\
\end{tabular} & $\begin{array}{c}\text { JHPIS Sec. 1-1: } \\
\text { Grade 1 }\end{array}$ & B & $\begin{array}{l}\text { JHPIS Sec. 1-1: } \\
\text { Grade } 2 \text { or over }\end{array}$ \\
\hline $\begin{array}{l}\text { CASBEE } \\
\text { LR }_{\mathrm{H}} 21.1: \\
\text { Level } 4 \\
\text { or over }\end{array}$ & A & $\begin{array}{l}\text { Domestic } \\
\text { wood }\end{array}$ & Raw materials & & $\begin{array}{l}\text { Wind } \\
\text { resistance }\end{array}$ & $\begin{array}{l}\text { JHPIS Sec. 1-4: } \\
\text { Grade 1 }\end{array}$ & A & $\begin{array}{l}\text { JHPIS Sec. 1-4: } \\
\text { Grade } 1 \text { or over }\end{array}$ \\
\hline $\begin{array}{l}\text { JHPIS Sec. } \\
\text { 3-1: Grade } 2 \\
\text { or over }\end{array}$ & B & 30 years & Durability & Exterior & $\begin{array}{l}\text { Fire } \\
\text { resistance }\end{array}$ & $\begin{array}{c}\text { JHPIS Sec. 2-6: } \\
\text { Grade } 3\end{array}$ & A & $\begin{array}{l}\text { JHPIS Sec. 2-6: } \\
\text { Grade } 3 \text { or over }\end{array}$ \\
\hline $\begin{array}{l}\text { JHPIS Sec. } \\
\text { 5-1: Grade } 4\end{array}$ & $\mathrm{C}$ & $\begin{array}{l}\text { JHPIS Sec. } \\
\text { 5-1: Grade } 1\end{array}$ & $\begin{array}{c}\text { Thermal } \\
\text { insulation } \\
\text { performance }\end{array}$ & $\begin{array}{l}\text { Thermal } \\
\text { insulation }\end{array}$ & \begin{tabular}{|c|} 
Thermal \\
insulation \\
performance
\end{tabular} & $\begin{array}{c}\text { JHPIS Sec. 5-1: } \\
\text { Grade } 1\end{array}$ & $\mathrm{C}$ & $\begin{array}{c}\text { JHPIS Sec. 5-1: } \\
\text { Grade } 4\end{array}$ \\
\hline $\begin{array}{l}\text { JHPIS Sec. } \\
\text { 5-1: Grade } 4\end{array}$ & $\mathrm{C}$ & $\begin{array}{l}\text { JHPIS Sec. } \\
\text { 5-1: Grade } 2\end{array}$ & $\begin{array}{c}\text { Thermal } \\
\text { insulation } \\
\text { performance }\end{array}$ & \multirow{2}{*}{$\begin{array}{l}\text { Windows } \\
\& \text { doors }\end{array}$} & $\begin{array}{c}\text { Area of } \\
\text { window } \\
\text { openings }\end{array}$ & $\begin{array}{l}22 \% \text { of the } \\
\text { floor area }\end{array}$ & A & $\begin{array}{c}20 \% \text { of the } \\
\text { floor area or } \\
\text { more }\end{array}$ \\
\hline $\begin{array}{c}\text { CASBEE } \mathrm{Q}_{\mathrm{H}} 1 \\
\begin{array}{c}1.1 .2: \text { Level } 4 \\
\text { or over }\end{array}\end{array}$ & B & $\begin{array}{l}\text { CASBEE } \mathrm{Q}_{\mathrm{H}} 1 \\
\text { 1.1.2: Level } 3\end{array}$ & $\begin{array}{c}\text { Sunlight } \\
\text { adjustment } \\
\text { capability }\end{array}$ & & \begin{tabular}{|c|} 
Sound \\
insulation \\
performance
\end{tabular} & $\begin{array}{c}\text { JHPIS Sec. 8-4: } \\
\text { Grade } 1\end{array}$ & B & $\begin{array}{l}\text { JHPIS Sec. } 8-4 \text { : } \\
\text { Grade } 2 \text { or over }\end{array}$ \\
\hline $\begin{array}{c}\text { CASBEE } \\
\mathrm{LR}_{\mathrm{H}} 21.4: \\
\text { Level } 4 \\
\text { or over } \\
\end{array}$ & A & $\begin{array}{l}\text { CASBEE } \\
\text { LR }_{\mathrm{H}} 2 \text { 1.4: } \\
\text { Level } 4\end{array}$ & Raw materials & $\begin{array}{l}\text { Interior } \\
\text { finishing }\end{array}$ & $\begin{array}{l}\text { Formal- } \\
\text { dehyde } \\
\text { emission }\end{array}$ & $\begin{array}{c}\text { JHPIS Sec. 6-1: } \\
\text { Grade } 3\end{array}$ & A & $\begin{array}{c}\text { JHPIS Sec. 6-1: } \\
\text { Grade } 3\end{array}$ \\
\hline $\begin{array}{l}\text { JHPIS Sec. } \\
\text { 4-1: Grade } 3 \\
\text { or over }\end{array}$ & B & $\begin{array}{l}\text { JHPIS Sec. } \\
\text { 4-1: Grade } 2\end{array}$ & $\begin{array}{c}\text { Consideration } \\
\text { for } \\
\text { maintenance }\end{array}$ & Piping & & & & \\
\hline $\begin{array}{l}\text { Energy usage } \\
\text { of the whole } \\
\text { home or more }\end{array}$ & $\mathrm{C}$ & 0 (Zero) & $\begin{array}{c}\text { Harnessed } \\
\text { natural energy }\end{array}$ & $\begin{array}{c}\text { Equipment } \\
\text { for harnessing } \\
\text { natual energy }\end{array}$ & & & & \\
\hline \multirow{2}{*}{$\begin{array}{l}\text { Hedge or } \\
\text { Resources } \\
\text {-saving } \\
\text { materials }\end{array}$} & \multirow{2}{*}{ A } & \multirow{2}{*}{ Hedge } & \multirow{2}{*}{ Material } & \multirow{2}{*}{ Fence } & \multirow{2}{*}{ Form } & $\begin{array}{l}\text { Not blocking } \\
\text { sight line }\end{array}$ & A & $\begin{array}{l}\text { Not blocking } \\
\text { sight line }\end{array}$ \\
\hline & & & & & & $\begin{array}{l}\text { Not blocking } \\
\text { communication }\end{array}$ & A & $\begin{array}{l}\text { Not blocking } \\
\text { communication }\end{array}$ \\
\hline \multirow[t]{2}{*}{$\begin{array}{c}\text { Places } \\
\text { receiving } \\
\text { sunlight } \\
\end{array}$} & A & $\begin{array}{c}\text { Places } \\
\text { receiving } \\
\text { sunlight } \\
\end{array}$ & $\begin{array}{l}\text { Places in the } \\
\text { home }\end{array}$ & $\begin{array}{l}\text { Rooms used } \\
\text { at daytime }\end{array}$ & & & & \\
\hline & & & & $\begin{array}{l}\text { Specified } \\
\text { bedroom }\end{array}$ & $\begin{array}{c}\text { Relation } \\
\text { with toilet } \\
\text { and bath } \\
\end{array}$ & $\begin{array}{l}\text { On the same } \\
\text { floor }\end{array}$ & A & $\begin{array}{l}\text { On the same } \\
\text { floor }\end{array}$ \\
\hline $\begin{array}{c}\text { Building close } \\
\text { together }\end{array}$ & A & $\begin{array}{c}\text { Building close } \\
\text { together }\end{array}$ & Arrangement & $\begin{array}{l}\text { Rooms water } \\
\text { is used }\end{array}$ & & & & \\
\hline $40 \%$ or more & $\mathrm{C}$ & $15 \%$ & $\begin{array}{l}\text { Ratio to the } \\
\text { external area }\end{array}$ & Garden area & & & & \\
\hline
\end{tabular}

method, a sustainability checkup on a home as an object. This chapter examines the results of the sustainability checkup from two viewpoints: (1) the effects of this method on control system design, (2) comparison with existing assessment systems for sustainable homes.

The Effects of the Method on Control System Design. The two-step method is effective to promote designing practical control systems for sustainable homes in the following ways [3]. As shown in the results of the sustainability checkup, this method can smoothly identify necessary system components of such control systems, that is, a controlled object, controlled variables, and their desired values. In addition, a sustainability checkup table like Table 3 can clearly show both what should be controlled and the courses of control and help to design control laws.

Comparison with Existing Assessment Systems for Sustainable Homes. This section examines the value of this method, by comparing it with existing assessment systems for sustainable homes. In Japan, JHPIS and CASBEE for Home are used as public performance assessment systems for homes. Other countries of the world are also promoting such assessment systems, including 
EcoHomes of BREEAM, LEED for Homes, and Green Star. BREEAM in the United Kingdom is one of the most comprehensive and widely recognized measures of a building's environmental performance [6]; EcoHomes is a version of BREEAM for homes. LEED in the United States is an internationally recognized green building certification system [7]; LEED for Homes is a home version of LEED. Green Star in Australia is a comprehensive, national, voluntary environmental rating system for buildings [8]. These public assessment systems contain a variety of essential information; therefore, we referred to them when compiling Table 2. On the other hand, as compared with these existing assessment systems, this method has the following advantages.

(1) Simplicity and clarity: Table 2 is easy to understand because it simply and clearly shows the relationship between the standard home and sustainable development.

(2) Systematic: Table 2 systematically demonstrates the relationship between the elements of the standard home and both the natural environment and humans' well-being. Accordingly, it provides balanced and comprehensive understanding of the relationship.

(3) Ease of use: All of the elements shown in Table 3 are equivalent to real parts of homes. Therefore, when conducting a checkup on a home by using a checkup sheet like Table 3 , designers simply check the home's parts which correspond to the elements. As a result, they can easily assess the variables of the elements.

(4) Ease of finding measures for improvement: The results of a sustainability checkup like Table 3 show the elements which should be controlled, controlled variables, and their desired values, all at the same time. Therefore, such a checkup enables designers to understand both what should be improved and the courses of improvement and helps to find measures for improvement.

The above advantages also show the effectiveness of the two-step method for designing practical control systems for sustainable homes.

\section{References}

[1] K. Fujihira, K. Osuka, T. Yoshioka, and N. Hayashi: An Educational Methodology for Sustainable Development Applying Control Theory and Confirming its Validity, Environmental Education, Vol. 18-1, pp. 17-28 (2008) (in Japanese).

[2] K. Fujihira and K. Osuka: An Educational Methodology for Sustainable Development, ICCAS-SICE2009 (2009).

[3] K. Fujihira and K. Osuka: An Approach to Designing Control Systems for Sustainable Development, SICE2011 (2011), in press.

[4] Japanese Ministry of Land, Infrastructure and Transport (JMLIT): Japan Housing Performance Indication Standards, JMLIT (2001) (in Japanese).

[5] Japan Sustainable Building Consortium and Japan GreenBuild Council: Comprehensive Assessment System for Building Environmental Efficiency (CASBEE) for Home - Technical Manual 2007 Edition, Institute for Building Environment and Energy Conservation (2007).

[6] Information on http://www.breeam.org/page.jsp?id=66.

[7] Information on http://www.usgbc.org/DisplayPage.aspx?CMSPageID=1988.

[8] Information on http://www.gbca.org.au/green-star/green-star-overview/ 